\title{
Further Dihydrochalcones from Crotolaria ramosissima
}

\author{
J.K. Kumar ${ }^{\mathrm{a}}$, T. Narender ${ }^{\mathrm{a}}$, M.S. Rao ${ }^{\mathrm{a}}$, P.S. Rao ${ }^{\mathrm{a}}$, G. Tóth $^{*}, \mathrm{~b}$, \\ B. Balázs ${ }^{\mathrm{b}}$, and H. Duddeck*, \\ ${ }^{a}$ Department of Chemistry, Kakatiya University, Warangal (A.P.) 506 009, India \\ ${ }^{\mathrm{b}}$ Technical Analytical Research Group of the Hungarian Academy of Sciences, Institute \\ for General and Analytical Chemistry of the Technical University, Szent Gellért tér 4, \\ H-1111 Budapest, Hungary \\ ${ }^{\mathrm{c}}$ Universität Hannover, Institut für Organische Chemie, Schneiderberg $1 B$, \\ D-30167 Hannover, Germany
}

Duas novas 2,3-diidrohalconas crotaramin (2) e crotin (3) foram isoladas da planta da Índia Crotolaria ramosissima. Suas estruturas foram elucidadas por meio de intenso uso de espectroscopia de RMN uni- e bidimensional, incluindo HMBC e NOESY.

Two new dihydrochalcones, crotaramin (2) and crotin (3), have been isolated from the Indian plant Crotolaria ramosissima. Their structures have been elucidated by extensive one- and two-dimensional NMR spectroscopy including HMBC and NOESY.

Keywords: dihydrochalcones, Crotolaria ramosissima, structure elucidation, $1 D$ and $2 D$ ${ }^{1} \mathrm{H}$ and ${ }^{13} \mathrm{C}$-NMR spectroscopy

\section{Introduction}

Crotolaria ramosissima is a weed plant belonging to the family Leguminoseae. It is a much branched sticky woody herb. The flowers are yellow tinged with purple. It is distributed in some places of Tamilnadu and coastal areas of Andrha Pradesh. The plant contains waxes, and, when flowering, a yellow exudate appears in the inflorescences. Recently ${ }^{1}$, we published the corrected structure of crotaramosmin (1) from crotolaria ramosissima which appeared to be a dihydrochalcone, a class of compound which is rare as a plant secondary metabolite. Except $\mathbf{1}$, only one other instance of a dihydrochalcone possessing a chromenyl moiety has been reported in the literature ${ }^{2}$. This is a synthetic compound and has an unsubstituted phenyl ring (see Scheme 1: $\mathrm{X}=\mathrm{Y}=\mathrm{H}$ ). Our continued interest on crotolaria ramosissima led to the identification of two more dihydrochalcones, crotaramin (2) and crotin (3) (Scheme 1).

\section{Results and Discussion}

The identification of the two new dihydrochalcones was based on extensive 1D and 2D NMR spectroscopy as described before ${ }^{3,4}$. The ${ }^{1} \mathrm{H}$ and ${ }^{13} \mathrm{C}$ chemical shifts are collected in Table 1. The assignments were confirmed by
DEPT experiments which allowed the differentiation between the $\mathrm{CH}_{n}(\mathrm{n}=0-3)$ fragments and further by HMQC experiments providing the assignment of the hydrogens to the directly attached carbon atoms. Long-range ${ }^{1} \mathrm{H},{ }^{13} \mathrm{C}$ correlations (via more than one bond; HMBC, optimized to a ${ }^{13} \mathrm{C},{ }^{1} \mathrm{H}$ coupling constant of $7 \mathrm{~Hz}$ ) afforded the unequivocal assignment of the quaternary carbons and the connectivity within the carbon framework. For example, C-5' and C-9' gave rise to very close ${ }^{13} \mathrm{C}$ signals, $\delta=159.7$

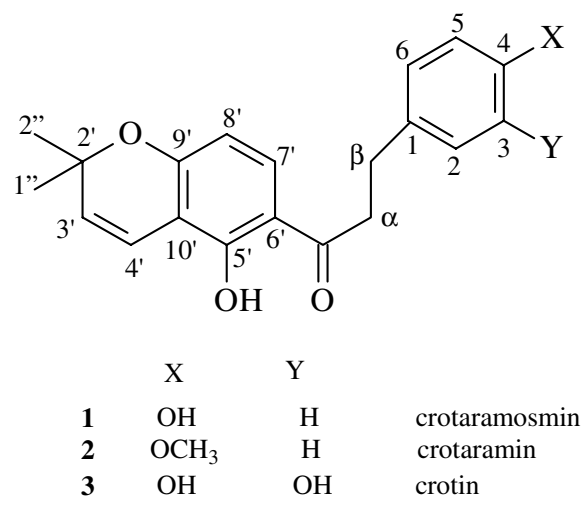

Scheme 1. Structures of 1 - 3 
Table 1. ${ }^{1} \mathrm{H}$ and ${ }^{13} \mathrm{C}$ chemical shifts of the dihydrochalcones $\mathbf{2}$ and $\mathbf{3}$.

\begin{tabular}{|c|c|c|c|c|}
\hline position & $\begin{array}{c}\mathbf{2} \\
{ }^{1} \mathrm{H} \\
\end{array}$ & $\begin{array}{c}3 \\
{ }^{1} \mathrm{H} \\
\end{array}$ & $\begin{array}{c}2 \\
{ }^{13} \mathrm{C} \\
\end{array}$ & $\begin{array}{c}\mathbf{3} \\
{ }^{13} \mathrm{C} \\
\end{array}$ \\
\hline 1 & & & 132.9 & 134.0 \\
\hline 2 & 7.16 & 6.76 & 129.3 & $115.44 *$ \\
\hline 3 & 6.85 & & 114.0 & 143.6 \\
\hline 4 & & & 158.1 & 141.9 \\
\hline 5 & 6.85 & 6.79 & 114.0 & $115.48 *$ \\
\hline 6 & 7.16 & 6.66 & 129.3 & 120.7 \\
\hline$\alpha$ & 3.19 & 3.17 & 39.8 & 39.7 \\
\hline$\beta$ & 3.00 & 2.94 & 29.6 & 29.8 \\
\hline $\mathrm{C}=\mathrm{O}$ & & & 203.9 & 203.9 \\
\hline $2^{\prime}$ & & & 77.7 & 77.7 \\
\hline $3^{\prime}$ & 5.59 & 5.58 & 128.2 & 128.2 \\
\hline $4^{\prime}$ & 6.73 & 6.72 & 115.8 & 115.8 \\
\hline 5 & & & 159.7 & 159.7 \\
\hline $6^{\prime}$ & & & 113.4 & 113.4 \\
\hline $7^{\prime}$ & 7.53 & 7.52 & 130.8 & 130.9 \\
\hline $8^{\prime}$ & 6.32 & 6.32 & 108.3 & 108.3 \\
\hline $9^{\prime}$ & & & 159.6 & 159.6 \\
\hline $10^{\prime}$ & & & 109.3 & 109.3 \\
\hline $1 "$ & 1.46 & 1.46 & 28.3 & 28.3 \\
\hline 2" & 1.46 & 1.46 & 28.3 & 28.3 \\
\hline $5^{\prime}-\mathrm{OH}$ & 13.05 & 13.02 & & \\
\hline 4-MeO & 3.80 & & 55.3 & \\
\hline
\end{tabular}

* Asterisked values may be interchanged. and 159.6, respectively. Their assignment could be accomplished by an HMBC peak correlating the 159.6-signal to those of the methyl protons $\mathrm{H}-1$ " and $\mathrm{H}-2$ ". Only in one case, $\mathrm{C}-2$ and $\mathrm{C}-5$ of $\mathbf{3}$, the signals were so close that the resolution in the ${ }^{13} \mathrm{C}$ domain of the HMBC spectrum was not good enough for a safe assignment.

NOESY experiments were helpful in corroborating the bicyclic chromene structure because they ascertained the spatial proximity between $\mathrm{H}-8$ ' and the methyl protons H-1" and H-2" (compare Scheme 2) so that a benzene ring carrying a prenyl side chain could be excluded.

The position of the hydroxyl groups was obvious from the ${ }^{1} \mathrm{H},{ }^{1} \mathrm{H}$ coupling constants: ${ }^{3} J\left(\mathrm{H}-7, \mathrm{H}^{\prime} 8^{\prime}\right)=8.8 \mathrm{~Hz}$ (ortho-coupling); typical $\mathrm{AA}^{\prime} \mathrm{XX}$ ' sub-spectrum for $\mathrm{H}$ 2/H-3/H-5/H-6 in 2; although the spin-system of H-2, H-5 and $\mathrm{H}-6$ in $\mathbf{3}$ is not entirely first-order, the coupling pattern could be detected and the respective constants are ${ }^{3} J(\mathrm{H}-5$, $\mathrm{H}-6) \approx 8 \mathrm{~Hz}$ and ${ }^{4} J(\mathrm{H}-2, \mathrm{H}-6) \approx 2 \mathrm{~Hz}$. The $\alpha$ - and $\beta$-protons show the expected triplets.

It turned out that $\mathbf{2}$ is the 4- $O$ methyl ether of $\mathbf{1}$ whereas an extra hydroxyl group in 3-position is present in $\mathbf{3}$, as compared to $\mathbf{1}$. Both dihydrochalcones have not yet been described in the literature.

\section{Experimental}

The plant material was collected in november 1997 near the city of Hyderabad. It was identified by Dr. V.S. Raju and Dr. Ragan, Department of Botany, Kakatiya University, Warangal. A voucher specimen is deposited in the Department of Botany.

The fresh plant material $(2 \mathrm{~kg})$ was extracted with petroleum ether in a soxhlet extractor. The extract was concentrated under reduced pressure to give a dark yellow syrupy liquid. The concentrate was dissolved in $\mathrm{MeOH}$ and

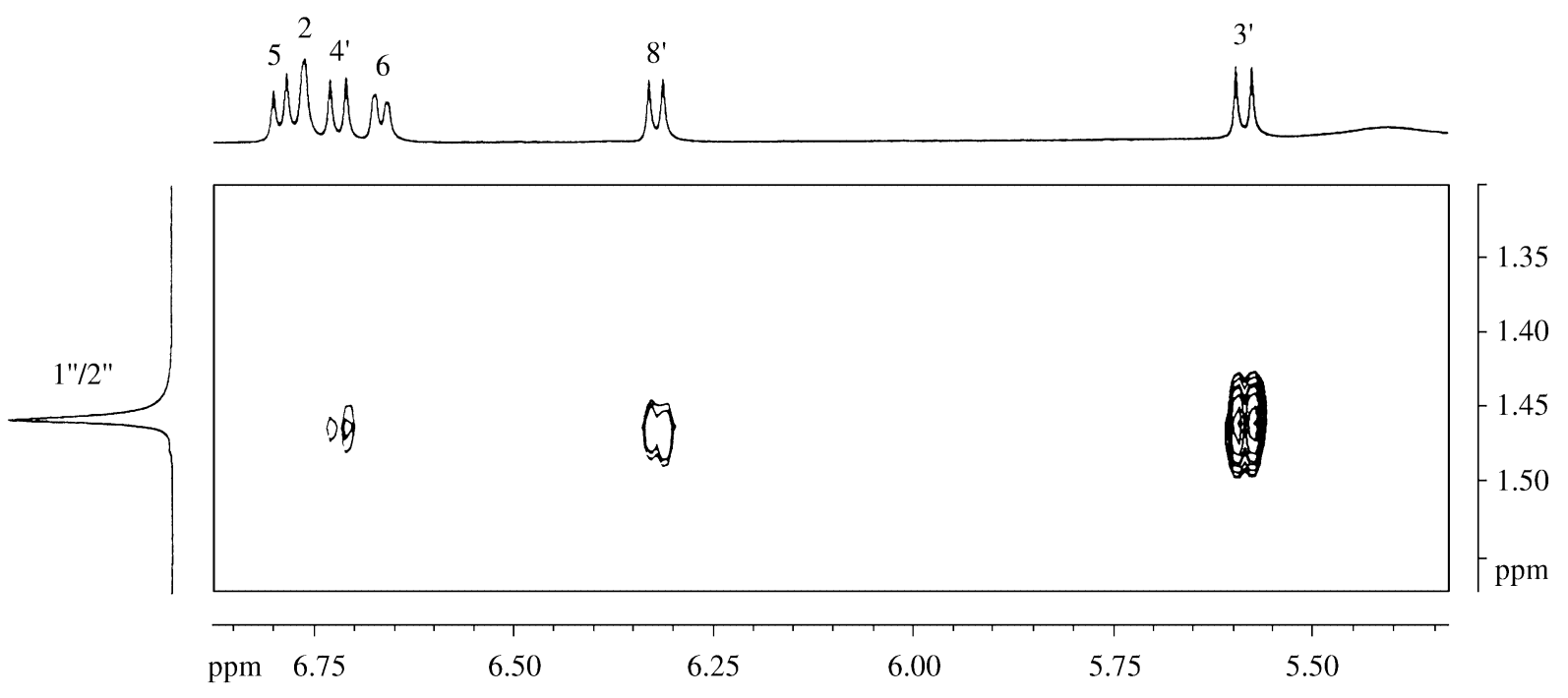

Scheme 2. Section of the NOESY spectrum of $\mathbf{3}$. 
kept in a refrigerator for a week. The separated waxy material was filtered off, and this procedure was repeated several times to remove a maximum amount of wax. The methanolic solution ( $2 \mathrm{~g}$ ) was chromatographed over silica gel (100-200 mesh) and eluted with petrol ether with increasing quantities of ethyl acetate. The fractions obtained from petrol ether-ethyl acetate (95:5) showed a single spot on TLC. These fractions were collected and evaporated to give a colourless solid which yielded colourless needles $(120 \mathrm{mg})$ of crotaramin $(2)$ on recrystallization from methanol; m.p. $62^{\circ} \mathrm{C}$.

Further elution of the column with petrol ether/ethyl acetate (85:15) fractions showed another single spot on TLC. These fractions were separated and concentrated to get a pale yellow solid which was recrystallized with methanol and yielded pale yellow prisms $(100 \mathrm{mg})$ of crotin (3); m.p. $105^{\circ}$.

Both compounds were optically inactive and gave a dark green ferric reaction. Crotin (3) gave a red coloration with aqueous $\mathrm{KOH}$. The UV spectra were recorded on a Shimadzu UV-240 and the IR spectra on a Nicolet-740 spectrophotometer. The NMR spectra were obtained on a Bruker DRX-500 spectrometer $\left(500 \mathrm{MHz}{ }^{1} \mathrm{H}\right.$ and $125 \mathrm{MHz}$ ${ }^{13} \mathrm{C}$ ) in $\mathrm{CDCl}_{3}$; for the experimental conditions see ref. 3 . Electron-impact mass spectra were recorded on a Finnigan MAT-312.

1-(5-hydroxy-2,2-dimethyl-2H-1-benzopyran-6-yl)-3(4-methoxyphenyl)-1-propanone; crotaramin (2)

UV (nm): 225, 266, $306(\mathrm{MeOH}) ; 210,264,310$ $(\mathrm{MeOH} / \mathrm{MeONa}) ; 224,267,340\left(\mathrm{AlCl}_{3}\right) ; 223,266,338$ $\left(\mathrm{AlCl}_{3} / \mathrm{HCl}\right) ; 226,256,305$ (NaOAc); 224, 266, 305 $\left(\mathrm{NaOAc} / \mathrm{H}_{3} \mathrm{BO}_{3}\right)$. IR $(\mathrm{KBr}) \mathrm{cm}^{-1}: 2964,1614,1514,1462$, 1425, 1290, 1244, 1032, 943, 881, 731. EI-MS m/z (\%) 338 $\left(24, \mathrm{M}^{+}\right), 323\left(100, \mathrm{M}^{+}-\mathrm{CH}_{3}\right), 305$ (3), 217 (2), 203 (6), 187 (4), 161 (3), 121 (41), 99 (5), 78 (3).
1-(5-hydroxy-2,2-dimethyl-2H-1-benzopyran-6-yl)-3-

(3,4-dihydroxyphenyl)-1-propanone; crotin (3)

UV (nm): 207, 233, $265(\mathrm{MeOH}) ; 209,235,329$ $(\mathrm{MeOH} / \mathrm{MeONa}) ; 208,232,265\left(\mathrm{AlCl}_{3}\right) ; 208,232,265$ $\left(\mathrm{AlCl}_{3} / \mathrm{HCl}\right) ; 208,231,266$ (NaOAc); 220, 233, 269 $\left(\mathrm{NaOAc} / \mathrm{H}_{3} \mathrm{BO}_{3}\right)$. IR (KBr) cm $\mathrm{cm}^{-1}: 3449,3332,2942,1870$, 1749, 1640, 1528, 1486, 1440, 1362, 1280, 1242, 1192 , 1115, 806. EI-MS m/z (\%) $340\left(28, \mathrm{M}^{+}\right), 325\left(100, \mathrm{M}^{+}-\right.$ $\mathrm{CH}_{3}$ ), 309 (7), 307 (7), 217 (3), 203 (34), 187 (6), 185 (7), 161 (5), 160 (5), 124 (9), 99 (8), 77 (4).

\section{Acknowledgements}

The authors thank the Council of Scientific and Industrial Reseach (C.S.I.R.) for the award of a Senior Research Fellowship (SRF) to J.K.K.; M.S.R. and T.N. thanks the University Grants Commission (UGC) for a SRF award. This work was supported by the Deutsche Forschungsgemeinschaft, the Hungarian Academy of Sciences, the Hungarian National Research Foundation (OTKA: T026264) and the Fonds der Chemischen Industrie.

\section{References}

1. Rao, M.S.; Rao, P.S.; Tóth, G.; Balázs B.; Duddeck, H. J. Nat. Prod. 1998, 61, 1148.

2. Adityachaudhury, N.; Chowdhury, A.; Kirtaniya, C.; Chatterjee, A. Chem. Ind. (London) 1975, 179.

3.Elgamal, M.H.A.; Soliman, H.S.M.; Elmunajjed, D.T.; Tóth, G.; Simon A.; Duddeck, H. Magn. Reson. Chem. 1997, 35, 637.

4. Duddeck, H.; Dietrich, W.; Tóth, G. Structure Elucidation by Modern NMR - A Workbook; 3rd, revised and updated edition, 1998, Springer-Steinkopff, New York; exercise 25. 